\title{
Local Wisdom in Banjar Cultural Perspective
}

\author{
$\mathrm{Wahyu}^{1 *}$ \\ ${ }^{I}$ Faculty of Teacher Training and Education, Lambung Mangkurat University, Banjarmasin, Indonesia \\ ${ }^{*}$ Corresponding author.Email: wahyu@ulm.ac.id
}

\begin{abstract}
Local wisdom belongs to the local community. This local wisdom is lived, practiced, taught, and passed down from one generation to another which at the same time forms patterns of daily human behavior, both towards fellow human beings and towards nature. Local wisdom is noble values that are believed to be true, apply in the order of life of local communities, and aim to protect and manage the environment sustainably. South Kalimantan is one of the cities that has a variety of local wisdom, both local wisdom that has long been passed down from generation to generation as well as emerging local wisdom as a result of interaction with other communities and cultures. The current paradigm of modern science and technology has influenced the loss of some of the values of local wisdom. Therefore, efforts to explore, discover, build, and preserve the values of local wisdom are a necessity.
\end{abstract}

Keywords: Local wisdom, Banjar cultural, perspective.

\section{INTRODUCTION}

Indonesia is an archipelago, has thousands of islands and diverse ethnic groups. The people on each island have specificity in maintaining and utilizing their environment. In maintaining and utilizing the environment is very diverse and depends on environmental characteristics, for example, some people live on the banks of the river, on the beach, on the edge of the forest, in the mountains, and so on. The environment has grown their behavior, so they can continue to grow, develop, and adapt to their environment. They always take good care of their environment so that it does not cause problems in their lives. Also, they can enjoy the results of their environment, such as agriculture, plantations, fisheries, livestock. They are aware that the environment is where they move and where they live. The contribution of the environment to the survival of communities in various regions in Indonesia has fostered local wisdom [1].

This local wisdom has given color to Indonesian nationality. Each region has contributed to the national context. Various cultures in Indonesia have strengthened to Indonesia. This can be seen since 1928, various youth organizations from various regions established themselves as one unit [1]. This means how big the position of local wisdom values. The value of local wisdom must be seen as a social heritage, believed to have valuable values for the pride and greatness of the nation's dignity. Therefore, the transmission of the value of local wisdom to future generations is a necessity. In-Law No. 32 of 2009 concerning environmental protection and management (PPLH), that local wisdom can be interpreted as a value that applies in the life of the community to protect and manage the environment so that it is sustainable so that local wisdom is used as a basis or basis when carrying out environmental protection and management life.
South Kalimantan is a city that has a variety of local wisdom, both local wisdom that has long been passed down from generation to generation as well as emerging local wisdom as a result of interaction with people and other lives. Local wisdom must be raised and preserved again because local wisdom is implicitly the identity of the region. Likewise, along with the increase in cultural information technology towards modern life and the influence of globalization, the local wisdom of the community faces the challenge of its existence.

\subsection{Understanding Local}

Wisdom comes from the word wisdom. According to the Big Indonesian Dictionary, wisdom has two meanings, namely knowing or knowing. The second meaning is clever, clever, and wise. The word wise if you add the prefix "to" and the suffix "an" into wisdom means wisdom, intelligence as a necessity for interaction. The word local, which means a place or at a place or at a place to grow, is there, living something that may be different from other places or places in a place of value that may be local or may also be universally valid [2].

Etymologically, local wisdom is called local policy (Local Wisdom), local knowledge, and local intelligence (Local Genius). From some of the above meanings, local wisdom contains values, the perspective of the followers of society, which are dynamic and not static that tend to change from time to time. The results of these thoughts reflect the original science and technology of the community which is often referred to as local culture (local wisdom), such as local wisdom in agriculture, health, food supply, education, natural resource management, and various other activities. Some experts mention local wisdom with the following definitions:

a. Sedyawati [3], local wisdom is defined as wisdom in the traditional culture of ethnic groups. Wisdom in the 
broadest sense is not only in the form of cultural norms and values, but also all elements of ideas, including those that have implications for technology, health care, and aesthetics. With this understanding, what is included as a translation of local wisdom are various patterns of actions and the results of their metered culture.

b. Rosidi [4], the term local wisdom is the result of a translation from the local genius that was first introduced by Quaritch Wales in 1948-1949 which means the ability of local culture to deal with the influence of foreign culture when the two cultures are related.

c. Vlaenderen (1999), describes indigenous knowledge as a collection of ideas and assumptions used to guide, control, and explain actions in a specific arrangement based on a value system (religion and belief in supernatural things) and epistemology. He also then gave an understanding of the indigenous knowledge system as knowledge possessed and controlled by native communities in a systematic way [5].

d. Brouwer (1998), describes traditional knowledge as ancient abilities, original and special customs, conventions, and routines that embody a static view of community culture [5].

e. Kajembe (1999), describes indigenous technical knowledge including knowledge of tools and techniques for assessment, skills, change in shape, and use of resources that are specific to a location [5].

f. Related to the characteristics of local wisdom, Ellen, and Bicker [6], mentions several things including:

1) It is a collection of experiences and is rooted and produced by people who live in a certain place.

2) Transmitted orally, through imitation and demonstration.

3) It is a consequence of direct practice in daily life and is continually reinforced through experience and trial and error.

4) It tends to be empirical rather than theoretical knowledge in the narrow sense.

5) Repetition is a characteristic of tradition, even when new knowledge is added;

6) Always changing, produced and reproduced, found also lost, often represented as static;

7) Characteristic;

8) Socially uneven distribution;

9) Functional;

10) Holistic, integrative, and embodied in broader cultural traditions.

Based on the above definition it can be said that local wisdom encompasses traditions and practices that have been going on for a long time and are developing in a particular region, originating from that place or local communities embodied in community wisdom, knowledge, and learning. In many ways, this local wisdom is passed on from generation to person verbally from person to person and can take the form of stories, legends, fairy tales, ceremonies, songs, and even laws.

\section{METHOD}

This paper uses literature studies from various sources to analyze the local wisdom found in the Banjar community. Reference sources are from journals and books that are relevant to this article.

\section{RESULT AND DISCUSSION 3.1 Local Wisdom Values}

Every community has an order of social and cultural values that can be located as social capital. The attitude and behavior of the people who are directing, because it is based on values believed to be true and this is a form of local wisdom. Gobyah [7] interprets local wisdom as a truth that has been directed or fixed in an area.

Values in socio-cultural relations relate to the price of appropriateness or the price of kindness, which can be said to be important and not important, or deep and superficial, but these qualifications cannot be measured quantitatively [3].

Cultural values are things that are considered good, right, and or appropriate, as agreed in the community. Thus, cultural values are formulated in culture and implemented in society, and expressed in self-direction or interaction, directly or indirectly, between community members, in various types of activities. Self-direction guided by cultural values refers to acceptance in society. Therefore, cultural values are by themselves social and cultural [3].

Local wisdom is an entity that determines the dignity of human beings in the community. Therefore, when the traditional values that exist in the community are uprooted from local cultural roots, the community will lose its identity and identity, as well as lose its sense of pride and sense of belonging. Efforts to explore, discover, build, and transmit morals and values come from local excellence because their wisdom becomes a necessity.

The content in a cultural form is abstract and is often vague and hidden. In this context, there are several values of local wisdom, namely:

a. Knowledge belongs to the local community. There is no knowledge of local wisdom that is individual. Local wisdom knowledge is owned and shared collectively for fellow community members. It is open to be known, even must be taught openly to be owned and loved by all members of the community. Here are the values of kinship and respect.

b. Manage the environment well. Knowledge of local wisdom is knowledge of how to live well with all the contents of nature. This knowledge also includes how to treat each part and life in nature in such a way, both to maintain the life of each species and to maintain all life in the universe itself. Everything has provisions as practical knowledge and norms that guide its implementation.

c. Nature is full of values and moral messages. Local people, nature is not seen merely as objects and tools for human interests. Nature sends messages and moral commands to obey humans, including moral messages in the form of respect for life. Because nature is a relative, in itself there is a value that must be obeyed. 
d. Moral activity. Farming, hunting, and fishing are not merely scientific activities in the form of applying scientific knowledge, which is guided by rational scientific principles and understanding. These activities are moral activities that are guided and based on moral principles or taboos that originate from local wisdom. These activities are not all, only a part of which can be explained rationally according to the size of science. It can only be understood in terms of local wisdom. For example, some villages in West Java, when they are about to start cutting or cutting rice, are often preceded by prayers and offerings (food types). This cannot be explained scientifically rationally. All this can only be understood in terms of the embodiment of local wisdom, namely humans, nature, and the relationship between them and nature. This can only be understood in the context that their activities are moral [8].

From this, it can be concluded that the practice of local wisdom is very valuable and has benefits for people's lives. The practice of local wisdom views humans as an integral part of nature and has relations with all beings in the universe. They never try to live a life that is only concerned with relationships with others, but also relations with the surrounding nature: with forests, with the sea, with lakes, with rivers, with mountains and with animals and plants in nature. Therefore, it can be understood that the practice of local wisdom is the efforts of local communities to manage environmental quality. Environmental quality is only associated with environmental problems, such as pollution, erosion, and flooding. Good environmental quality can be interpreted as environmental conditions about quality of life. The higher the quality of life in a particular environment, the higher the quality of the environment and vice versa

\subsection{Local Wisdom the Banjar People}

South Kalimantan has a lot of cultural wealth. Thus, it is important to explore local wisdom related to meaning and function for present and future conditions. The life pattern of the people of South Kalimantan, especially for the Banjar tribe, almost $80 \%$ from upstream to downstream is characterized by a distinctive culture that is river culture. On the contrary, this is different from agrarian or inland cultures that have a strong awareness of land ownership. In South Kalimantan, rivers since ancient times were understood as the main traffic lane between one area and another so Banjarmasin is often dubbed as the River City or the City of the Thousand Rivers [9].

In subsequent developments, Banjar culture underwent a process of acculturation, mixing with other cultures such as Dayak culture, Javanese culture, Malay culture which were wrapped together in the Banjar culture dress [9]. Thus, Banjar culture has a democratic character. This is marked by the very opening and fading culture Banjaraccepts various other cultures that were originally foreign. He can position these other cultures as equal partners and equal dialogue partners in his locus. As such, Banjar society is egalitarian, equal, and democratic and far from tribal fanaticism. Entering more deeply the values of local wisdom in Banjar culture, this can be called several forms, including:

\subsubsection{The Tradition of Deliberation and Justice}

Democratic values began when Sultan Suriansyah (1526$1545)$ as the first king of the Banjar kingdom governed his governance. The first step taken by the Sultan was not to choose the position of Patih and Mangkubumi from the aristocratic group owned by the royal family but was taken from Urang Jaba (ordinary people) who had the ability and high dedication to the kingdom. The first person chosen as the king by the will of the general public at that time was Patih Masih, a fisherman's child on the banks of the Martapura River, precisely in the Kuin area. Likewise, the tradition of justice in the Banjar community has long been developed. There is a kind of justice institution called the Syar'iyah Court headed by a Mufti. The task of the Mufti is to provide a fatwa for those who want to carry out the legal process by displaying a stamped proof or the legality of the Sultan's signature [9].

\subsubsection{Mutual Cooperation}

Tradition cooperation as a feature of democracy also lives in Banjar society. There is a well-known phrase that holds the life of the Banjar community; Gawi Sabumi Sampai Manuntung (working together to completion) or Waja sampai Kaputing (working together from beginning to end) or Kayuh Baimbai (rowing simultaneously). This means that in carrying out work until it is completed by working together, rambate rata hayu, carry the same weight, and carry the same weight.

\subsubsection{Freedom Tradition}

Since childhood, Banjar children have been trained and educated by their parents to be free to choose their way of life so that they can become independent quickly. This is closely related to the trading culture of the Banjar people, which is so strong. The intended freedom is more in the economic field. Some are invited to trade small, just to help their parents sell, learn to work odd jobs by choosing modest rewards, be warned about the ins and outs of trading or want to continue school as much as possible. For Banjar people, the important thing is not to want to trade or want to go to school, but rather how to quickly release dependency on parents and be immediately free, independent, and independent.

\subsubsection{Tradition of Criticism}

The tradition of Criticism in Banjar culture is mostly expressed in art expressions. First, in Madihin art, one of the most popular traditional art of Banjar people is often in singing the poems of Pemadihin (now very famous John Tralala and his son Hendra) by slipping scathing criticism on anyone who is pretentious, pretentious, clever and smart great with subtle allusions wrapped in the language of rhymes, beautiful, poetic and humorous in the form of shouting dialogue or reciprocated poetry baturai poems that are familiar with the rhythm of the drum from flying (a kind 
of tambourine). Second, the legend of the story of the Palui which every day, faithfully present in the Banjarmasin Post Newspaper (the largest circulation newspaper in Banjarmasin). This figure is somewhat similar to the Kabayan figure in West Java, who is portrayed as an innocent, mischievous, quirky, unique human being, rather smart, stupid, smart, stupid, and a bit afraid to be afraid. He appeared as a critic of anyone he considered excessive, arrogant, and arrogant.

\subsubsection{Knowledge of Natural Symptoms}

Banjar tribe communities can find out natural phenomena through plants, animals, and stars in the sky. Various natural events are always experienced in the cycle of time, which sometimes occurs repeatedly, and finally, the symptoms can be calculated.

According to SR [10], traditional Banjar tribe people are usually able to find out natural phenomena by observing plants, animals, and stars in the sky. You name it when the ambawang tree (embacang) starts flowering, then they believe summer has arrived. The ambawang tree is a typical Banjar fruit tree. If the flower from the ambawang tree is dark red, then this indicates a hot tree that will last a long time, but if it is pink, then the arrow season will not belong.

\subsubsection{Knowledge of the Physical Environment}

Banjar people can find out the conditions and soil layers based on the plants that are above it. This is based on existing knowledge and from life experiences during the community. According to SR [10], Banjar people can determine soil fertility based on their experience. Soil is said to be fertile if there is a water source at the bottom layer. The clay and the loose layer of soil are thick, this is usually referred to as old soil. The type of soil that is declared suitable for agricultural land is often called cold land. Other knowledge is also often used by the community to determine whether or not the land for agriculture, for example, to determine soil fertility by looking at the types of plants that grow on it. Soil is classified as fertile land if it is with a type of belaran grass, kusisap, pipisangan and paku lembiding so that the land is good for agricultural land, but if it grows like parupuk, purun tikus, kumpai miang, benderang, and hahauran, then the land is not fertile.

\subsubsection{Knowledge of Plant Types, Benefits and Cultivation}

Community knowledge about plants or plants that accompany rice planting in the paddy fields is quite good and wise. The existing shipyard system planted with types of cucumbers, watermelons, corn, and other vines that can function as a means of controlling plant pests and mice can be known by examining plants grown in the yard. Therefore, plants that are planted are usually chosen that are preferred by rats so that it is easy to find out if there are rats in the paddy field and this is very helpful in its prevention. The living environment in the yard of the house is often planted with hard plants such as langsat tree to the border with leaves that are very strong and do not easily fall so that it does not pollute the yard. Besides, he is also planted with a mixture of medicines such as lemongrass, galangal, janar, jeriangau and rarely plant taro and sweets because they like to go to rats and become their hiding house. Likewise, with trees or plants (rambutan, kariwaya, which is believed to be a refuge for supernatural beings, so Banjar people who do not want to plant them near home).

The natural environment around the household can provide benefits for us as a coloring agent used for food and drinks which can then be used as a coloring agent in the manufacture of Sasirangan fabrics from time to time down and down. RD [10] mentions that dyes can be taken from various types of plants that are around our environment, such as yellow from janar and ginger. Red comes from gambier and noni fruit, red dolphin, or chili. Green comes from the leaves of pudak or ginger (tipakan). Black comes from kabuau or uar. Purple comes from ramania seeds (gandaria) or karamunting fruit. Chocolate comes from uar or rambutan fruit skin. The use of dyes derived from this plant is local wisdom that is friendly to the environment and does not endanger human health.

\subsubsection{Traditional House / Ceremony}

of South Kalimantan has a variety of traditional houses, namely as many as 11 (eleven) types of traditional Banjar houses which can be described as follows:

a. Banjar Traditional House with a bubungan tinggi Type;

b. Gajah Baliku Type

c. Gajah Manyusu

d. Balai Laki

e. Balai Bini

f. Palimasan

g. Palimbangan

h. Anjung Surung

i. Tadah Alas

j. Joglo

k. Lanting

Banjar traditional houses have their respective specifications both seen from the construction of the building and the background of its social history. According to SYR [10], the Banjar tribe community has a traditional house called the Banjar House from construction which is always in the form of houses on stilts. This type is environmentally sound because the land can function as a water catchment so that it can cope with flooding. This type of house on stilts by the local government has been used as a Perda in the construction of houses and shophouses. Likewise, the construction of poles and sticks with kacapuri systems still allows water to flow. The Banjar traditional house has wide doors. This is intended to facilitate air circulation so the house is always cool and fresh.

The Banjar tribe also has a house called Rumah Lanting (lanting house), a traditional Banjar house located on the river because the river was the main means of transportation in the past. Lanting houses, besides being used as dwellings, also function as a barrier to the erosion of river beaches because they can anticipate waves. The existence of lanting as a river attraction needs to be arranged neatly with an interesting architectural touch. 


\section{CONCLUSION}

Local wisdom of Banjar people grows and becomes part of Banjar culture and plays an important role in its development, including managing the environment containing moral values and messages, responsible behavior, respect, and care for the environment. All of this should be understood within the framework of environmental quality. The higher the quality of the environment, the higher the quality of life of the community in a particular environment.

There are many local pearls of wisdom that still exist in South Kalimantan, such as the tradition of deliberation and justice, the cooperation tradition, the tradition of freedom, the tradition of criticism, knowledge of the physical environment, knowledge of the types of plants, benefits, and cultivation, and traditional houses.

\section{REFERENCES}

[1] Rochgiyanti dkk, Kearifan Lokal Orang Dayak Bakumpai di Lahan Basah. Lembaga Penelitian Unlam: Aynat Publishing Yogyakarta, 2014.

[2] M. Fahmal, Peran Asas-Asas Umum Pemerintah yang Layak Dalam Mewujudkan Pemerintah yang Bersih. Yogyakarta: UII Press, 2006.

[3] E. Sedyawati, Budaya Indonesia, Kajian Arkeologi, Seni dan Sejarah. Jakarta: Raja Grafindo Persada, 2006.

[4] A. Rosidi, Kearifan Lokal dalam Perspektif Budaya Sunda. Bandung: Kiblat Buku Utama, 2011.

[5] M. \& A. F. Tillya, Appropriate Institutional Framework for Coordination of Indigenous Knowledge. 2003.

[6] E. R. and Bicker, Indigenous Environmental Knowledge and its Transformation Critical Anthropological Perspectives. Francis: The Taylor \& Francis e-Library, 2005.

[7] S. Ernawi, "Urban Culture, Urban Future, Harmonisasi Penataan Ruang dan Budaya Untuk Mengoptimalkan Potensi Kota," Harmonisasi kearifan lokal dalam Regulasi Penataan Ruang (Online), 2010. .

[8] S. Keraf, Etika Lingkungan. Jakarta: Penerbit Buku Kompas, 2002.

[9] H. Abdussami, Budaya Banjar dan Nilai-Nilai. Banjarmasin, 2014.

[10] Abidinsyah, "Internalisasi Nilai Peduli Lingkungan Melalui Pembelajaran Berbasis Kearifan Lokal: Studi di SDN Antasan Besar 7 Banjarmasin," UPI, 2012. 